\title{
Effects of Dietary Fermented Persimmon Diet on the Meat Quality of Fattening Pigs
}

\author{
Gyo Moon Chu', Suk Nam Kang ${ }^{1}$, Jung Man Nam, Hoi Yun Kim, Ji Hee Ha, \\ Rashid Ismael Hag Ibrahim², Jae Hong Park', II Suk Kim, and Young Min Song* \\ Department of Animal Resource Technology, Gyeongnam National University of Science and Technology, \\ Jinju 660-758, Korea \\ ${ }^{1}$ Swine Science \& Technology Center, Gyeongnam National University of Science and Technology, Jinju 660-758, Korea \\ ${ }^{2}$ Department of Horticulture, Gyeongnam National University of Science and Technology, Jinju 660-758, Korea
}

\begin{abstract}
The purpose of this study was to explore the effect of fermented persimmon diet on the meat quality of fattening pigs. Pigs ( $75 \mathrm{~kg}$ ) were grouped and housed as 15 animals per pen and 3 replications per treatment. The basal diet (C) was substituted with 3\% (T1), 5\% (T2) and 10\% (T3) of fermented diet. The 180 pigs were fed experimental diet for $42 \mathrm{~d}$ and 10 longissimus dorsi (LD) per treatment were collected when each swine reached $105.6 \mathrm{~kg}$ of body weight. The crude fat concentration of LD was lower $(p<0.05)$ in treatments, but the $\mathrm{pH}$ value of T3 and the shear force values of T2 and T3 were higher $(p<0.05)$ than those of C. The CIE L ${ }^{*}$ value (lightness) was significantly $(p<0.05)$ higher in T2 and T3 than $\mathrm{C}$, but the CIE $\mathrm{b}^{*}$ (yellowness) of T2 and T3 was significantly $(p<0.05)$ lower than $\mathrm{C}$. The composition of myristic acid and oleic acid was significantly $(p<0.05)$ higher in treatments than in $\mathrm{C}$, while the composition of palmitic acid and stearic acid of treatments were significantly $(p<0.05)$ lower than $\mathrm{C}$ in LD. Sensory evaluation of cooked meat as scores of aroma, taste, juiciness and overall acceptability showed higher $(p<0.05)$ in treatments than in C. In conclusion, the dietary of fermented persimmon diet decreased the crude fat concentration, improved the fatty acids composition (increased composition of unsaturated fatty acid and decreased composition of saturated fatty acid) and improved the sensory evaluation of pork meat from fattening pigs.
\end{abstract}

Key words: fermented diet, meat quality, persimmon, pigs

\section{Introduction}

The consumption of brand animal products is an increasing trend these days due to an ever expanding consumer's health conscious about ways of food production, thus, expanding animal farms specialized in brand products. One of the ways for such brand animal products is microorganism-fermented diet as a supplement feedstuff for pigs (Song et al., 2011). The microorganism-fermented diet improved gastrointestinal environment, such as decreased gastric $\mathrm{pH}$, number of enteric pathogens and incidences of clinical diseases, and increased concentration of gastric lactic acid (Kim et al., 2006; Lee et al., 2009). It was also reported that microorganism-fermented diet improved palatability and animal health (Canibe and Jensen, 2007;

\footnotetext{
*Corresponding author: Young Min Song, Department of Animal Resources Technology, Gyeongnam National University of Science and Technology, Jinju 660-758, Korea. Tel: 82-55-7513588, Fax: 82-55-751-3689, E-mail: pigsong@gntech.ac.kr
}

Kim et al., 2006).

Researchers studied beneficial microorganisms against high feed cost and also as antibiotic alternatives. Song et al. (2011) reported that dietary of fermented by-products diet improved the carcass grade and decreased the concentration of total cholesterol in the plasma, but did not affect the growth performance and feed efficiency of fattening pigs. Fermented diet also has negative impacts, such as its short storability due to high moisture contents (Westendorf, 2000), low digestibility and changed nutrient values (Chae et al., 2000), decrease of growth performance in growing-finishing pigs (Chae et al., 2000), marbling and change of soft fat in longissimus dorsi (LD) (So, 1999).

Persimmon (Diospyros kaki Thumb) is alkaline fruit that contains approximately $15 \%$ sugar, such as glucose and fructose, and it also contains over than $2 \%$ tannin and abundant of vitamin A and C (Taira et al., 1990). Tannins in persimmon affect the physiological activities and act as anti-bacterial agents, antioxidants and remove heavy met- 
als (Seo et al., 2000). Moreover, persimmon prevented arteriosclerosis by decrease of cholesterol concentration in the plasma (Gorinstein et al., 1998). Persimmon can be considered a good feedstuff, because it contains sugar, tannin and vitamins. However, to our knowledge, the fermented persimmon diet has not been developed as a feedstuff for livestock.

Experiments were conducted to investigate the effects of fermented persimmon diet based on microorganisms from pine needle that included Bacillus subtilis, Bifidobacterium pseudolongum, Lactobacillus acidophilus and yeast (Solsolk) on the pork meat quality of fattening pigs.

\section{Materials and Methods}

\section{Production of fermented persimmon diet}

The microorganisms used were Solsolk (Solip-Bio Inc., Korea) contained $1.40 \times 10^{7} \mathrm{CFU} / \mathrm{g}$ B. subtilis, $2.80 \times 10^{6}$ CFU/g B. pseudolongum, $6.50 \times 10^{7} \mathrm{CFU} / \mathrm{g}$ L. acidophilus and $8.60 \times 10^{6} \mathrm{CFU} / \mathrm{g}$ yeast. The fermented persimmon diet composed of $76.0 \%$ rice bran for controlled nutrient value, $20.0 \%$ dropped persimmon, $2.0 \%$ tinned peach byproduct, $1.0 \%$ brown rice vinegar by-product, $0.5 \%$ salt and $0.5 \%$ microorganisms. The ingredients mixed fermented in a fermenter (Bio-Rea, Tong yang, Seoul, Korea) at $37^{\circ} \mathrm{C}$ for $24 \mathrm{~h}$, then $1.5 \%$ illite, $2.0 \%$ limestone and $1.5 \%$ oak wood charcoal were added and mixed/fermented at $37^{\circ} \mathrm{C}$ for $12 \mathrm{~h}$. The mixture was transferred into $600 \mathrm{~L}$ plastic containers (anaerobic condition) and fermented at room temperature for $7 \mathrm{~d}$, and then the fermented persimmon diet was used as an experimental diet.

\section{Animals and diets}

The average body weight (BW) of experimental pigs was $75.3 \pm 1.0 \mathrm{~kg}$ at initiation. One hundred eighty crossed pigs (Landrace $\times$ Yorkshire $\times$ Duroc) were assigned to 4 dietary treatments based on BW and sex, and each treatment contained 15 pigs ( 8 barrows and 7 female mixed within pen) per pen and 3 replicates ( 15 pigs $\times 4$ diets $\times 3$ replications). They were given pre-feeding for $3 \mathrm{~d}$, had free access to water and fed experimental diet for $42 \mathrm{~d}$ (until 105.6 $\pm 3.0 \mathrm{~kg}$ of BW). The Guide for Care and Use of Laboratory Animals (Animal Care Committee of Gyeongnam National University of Science and Technology) was followed in this study. The basal diet as formula feed of fattening period contains approximately $33.47 \%$ corn, $23.00 \%$ wheat bran, $13.00 \%$ wheat and $30.52 \%$ of other additives as detail in Table 1 . The pigs were fed basal diet (C), while basal diet contained 3\% (T1), 5\% (T2) and
Table 1. Ingredients and chemical composition of basal diet

\begin{tabular}{lc}
\hline \multicolumn{1}{c}{ Items } & Basal diet \\
\hline Ingredients, as-fed basis, \% & 33.47 \\
Corn & 23.00 \\
Wheat bran & 13.00 \\
Wheat & 8.33 \\
Soybean meal, 44\% & 6.50 \\
Lupin kernel & 4.50 \\
Molasses & 3.00 \\
Palm kernel meal & 1.70 \\
Rice bran & 1.50 \\
Tallow & 1.00 \\
Rapeseed meal & 1.14 \\
Calcium phosphate, tribasic & 1.01 \\
Limestone & 0.95 \\
L-lysine hydrocholoric acid & 0.50 \\
Sodium chloride & 0.19 \\
Mineral Mix ${ }^{1)}$ & 0.16 \\
Vitamin Mix ${ }^{2)}$ & 0.05 \\
DL-methionine &
\end{tabular}

${ }^{1)}$ Provided per kg diet: $\mathrm{Cu}, 43 \mathrm{mg}$; $\mathrm{Zn}, 55 \mathrm{mg}$; Mn, $50 \mathrm{mg}$; Fe, $150 \mathrm{mg}$; Co, $0.5 \mathrm{mg}$; I, $0.5 \mathrm{mg}$; Se, $0.2 \mathrm{mg}$

${ }^{2)}$ Provided per kg diet: Vitamin A, 4,840 IU; Vitamin D3, 1,100 IU; Vitamin B2, $4.4 \mathrm{mg}$; Nicotinic acid, $22 \mathrm{mg}$; Vitamin B6, $1.65 \mathrm{mg}$; Vitamin B12, $0.22 \mathrm{mg}$; Biotin, $0.55 \mathrm{mg}$; Folic acid, $0.33 \mathrm{mg}$; Calcium pantothenic acid, $11 \mathrm{mg}$

$10 \%$ (T3) fermented persimmon diet were the treatments. The nutritional values of experimental diet are shown in Table 2.

\section{Sampling of longissimus dorsi and determination of chemical composition}

The pigs weighed on average approximately $106 \mathrm{~kg}$ at the end of this experiment. Experimental animals were transported to a normal abattoir near the experimental station and slaughtered by stunning with electrical tongs (300 volts for 3 seconds) $12 \mathrm{~h}$ after feed restriction. The shocked pigs were exsanguinated while hanged, then the carcasses were placed in a dehairer at $62^{\circ} \mathrm{C}$ for $5 \mathrm{~min}$ and remained hair was removed using a knife and flame. Carcasses were eviscerated, split and placed in a chiller set at $5^{\circ} \mathrm{C}$ for $12 \mathrm{~h}$.

The LD (6th to 13th rib) was randomly cut off and collected from 10 pigs in each treatment and kept at $5^{\circ} \mathrm{C}$ before it was transported to the Laboratory of Meat Science for the determination of chemical composition. The $\mathrm{pH}$, water holding capacity (WHC), shear force, cooking loss, meat color and sensory analysis were determined about $24 \mathrm{~h}$ after slaughter. The LD was frozen storaged at $-60^{\circ} \mathrm{C}$ for proximately analysis and fatty acid composition. The proximate analysis of moisture, crude protein, 
Table 2. Chemical composition of experimental diets and pork meat

\begin{tabular}{lrrrrr}
\hline \hline \multirow{2}{*}{ Items } & \multicolumn{5}{c}{ Treatments $^{1)}$} \\
\cline { 2 - 5 } & $\mathrm{C}$ & \multicolumn{1}{c}{$\mathrm{T} 1$} & $\mathrm{~T} 2$ & $\mathrm{~T} 3$ & \\
\hline Diet composition, \% & SEM $^{2}$ \\
Dry matter & & & & & \\
Crude protein & 16.05 & 85.21 & 84.79 & 83.72 & 0.24 \\
Crude fat & 6.41 & 6.39 & 6.37 & 6.33 & 0.05 \\
Crude fiber & 2.98 & 3.09 & 3.16 & 3.34 & 0.10 \\
Ash & 4.78 & 4.81 & 4.83 & 4.89 & 0.05 \\
Total calorie, Mcal/kg & 3.28 & 3.27 & 3.26 & 3.25 & 0.03 \\
\hline Meat composition, \% & & & & & \\
Moisture & 72.42 & 73.16 & 74.78 & 74.49 & 1.23 \\
Crude protein & 21.53 & 21.86 & 21.94 & 21.44 & 0.71 \\
Crude fat & $2.97^{\mathrm{a}}$ & $2.62^{\mathrm{b}}$ & $2.51^{\mathrm{b}}$ & $2.48^{\mathrm{b}}$ & 0.14 \\
Ash & 1.10 & 1.17 & 1.10 & 1.43 & 0.20 \\
\hline
\end{tabular}

${ }^{1)}$ The basal diet (C) was supplied 3\% (T1), 5\% (T2) and 10\% (T3) fermented persimmon diet.

${ }^{2)}$ Standard error of the means

${ }^{\mathrm{a}, \mathrm{b}}$ Values in the same row with different superscripts differ at $p<$ 0.05 .

crude fat and ash concentration of LD were determined according to the methods of AOAC (2000) until $4 \mathrm{wk}$ after storage.

\section{pH, water holding capacity, cooking loss and shear force}

A sample of $5 \mathrm{~g}$ was homogenized about $24 \mathrm{~h}$ postmortem in 10 volumes of distilled water (DW) using a polytrom homogenizer (MSE, USA). Hanna HI 9025 pH meter (Woonsocket, USA) with an Orion 8163 glass electrode (Berverly, USA) was used to determine $\mathrm{pH}$ values.

Water holding capacity (WHC) was determined by the centrifugal method of Honikel (1998). Each sample was measured 3 times and averaged.

For the cooking loss, $80 \mathrm{~g}$ of $1.5 \mathrm{~cm}$ thick LD was placed in a polyethylene bag. The packages were then kept in a water bath (DS-23S, Dasol, Korea) at $75^{\circ} \mathrm{C}$ for $1 \mathrm{~h}$ and cooled at RT for $30 \mathrm{~min}$. The cooking loss percentage was determined using the muscle weight that was taken before and after cooking.

Shear force was determined as described by Honikel (1998). The shear force was measured by an Instron 3343 (US/MX50, A\&D Co., USA) equipped with one WarnerBratzler shear blade (crosshead speed of $1 \mathrm{~mm} / \mathrm{second}$ ). Each sample was measured 3 times and averaged.

\section{Meat surface color}

Meat color of LD was evaluated on freshly cut surface (3 cm thick slice) using a Chroma Meter CR-300 (Minolta,
Japan) after $20 \mathrm{~min}$ at room temperature. Three color measurements were carried out across individual sample surfaces and the average of five replicates was expressed as CIE L ${ }^{*}$, CIE $a^{*}$ and CIE $b^{*}$. The Chroma Meter CR-300 was calibrated against a white tile $\left(\mathrm{L}^{*}=89.20, \mathrm{a}^{*}=0.921\right.$ and $\mathrm{b}^{*}=0.783$ ). The aperture was $8 \mathrm{~mm}$, illuminant D65 and $10^{\circ}$ Standard Observer.

\section{Fatty acid composition}

For the determination of fatty acids composition, total lipid was extracted using a modified Folch method as described by Ways and Hanahan (1964), and then saponification and esterification was conducted using a $0.5 \mathrm{~N}$ potassium hydroxide in methanol and $14 \%$ boron trifluoride methanol solution. Finally, the fatty acid methyl esters (FAME) in the hexane were injected to a gas chromatography (Agilent 6890+, Agilent HP, USA) fitted with a capillary column (HP-5MS capillary GLC column, $30 \mathrm{~m} \times 0.32 \mathrm{~mm}$ i.d. $0.25 \mathrm{~mm}$ film thickness, Agilent HP, USA) and a mass spectrometry detector (G1530A, Agilent HP, USA). The mass spectrometry interface and injector temperature were fixed at $270^{\circ} \mathrm{C}$ and $260^{\circ} \mathrm{C}$, respectively, and oven temperature was instituted to $160^{\circ} \mathrm{C}$ at $2.5 \mathrm{~min}, 160$ to $260^{\circ} \mathrm{C}$ at $4^{\circ} \mathrm{C}$ per min and then $260^{\circ} \mathrm{C}$ at $5 \mathrm{~min}$. Each fatty acid was identified by comparing its retention time with that of FAME standard (FAME Mix C8-C24, Supelco, USA) and expressed as a percentage of the standard.

\section{Texture profile analysis}

Texture profile analysis (TPA) of eight samples (2.00 $\mathrm{cm} \times 2.00 \mathrm{~cm} \times 2.0 \mathrm{~cm}$ ) from each treatment was assessed using an Instron 3343 (US/MX50, A\&D Co., USA) equipped with a cylindrically shaped plunger (5-mm diameter) and a 500-N load cell (Bourne, 1978; Szczceniak, 1963). To determine texture parameters including hardness, cohesiveness, springiness, gumminess, chewiness and adhesiveness, each sample cube was equilibrated to a room temperature and compressed twice to $50 \%$ of its original thickness at a constant speed of $60 \mathrm{~mm} / \mathrm{min}$. Texture profile parameters were calculated from the force deformation curves as follows: hardness ( $\mathrm{kg}$ f; force necessary to attain a given deformation, maximum force), cohesiveness (dimensionless, ratio; ratio of the positive force area during the second compression to that during the first compression excluding the areas under the decompression portion of each cycle), springiness (ratio; ratio of distances that the sample recover after the first compression), gumminess ( $\mathrm{kg}$ f; simulated energy required to disinte- 
grate a semisolid food to a steady state, hardness $\times$ cohesiveness) and chewiness ( $\mathrm{kg} \mathrm{f}$; hardness $\times$ cohesiveness $\times$ springiness).

\section{Sensory evaluation}

For sensory evaluation, a total of 35 panelists participated and conducted a duplicate test on each sample. Training of panelists was performed according to a sensory evaluation guideline (Meilgaard et al. 1991). The meat samples were cooked to an internal temperature of $74^{\circ} \mathrm{C}$ in a water bath and then cut into $10 \times 3 \times 25 \mathrm{~mm}^{3}$ pieces, placed on white plastic trays covered with aluminum foil and served immediately to each panelist. The cooked meat samples were evaluated for color $(1=$ very unacceptable; $9=$ very acceptable), off-flavor (1=very weak; $9=$ very strong), juiciness ( $1=$ very dry; $9=$ very juicy), flavor ( $1=$ very unacceptable; $9=$ very acceptable), tenderness (1=very tough; $9=$ very tender) and total acceptability (1= very unacceptable; $9=$ very acceptable).

\section{Statistical Analyses}

Data was analyzed with one-way ANOVA. General Linear Model (GLM) procedure of SAS (2008) was applied to conduct all analyses and significant differences among the means were determined using the Duncan's Multiple Range Test method (Duncan, 1955) and significant difference between means was examined at 5\% threshold.

\section{Results and Discussion}

\section{Diets and chemical composition of pork meat}

Effect of dietary fermented persimmon diet on the chemical composition of meat is shown in Table 2. The increasing of fermented persimmon diet decreased the concentration of dry matter, crude protein and total calorie, while increased that of crude fiber and ash concentration in experimental diet. In pork meat, although dietary of fermented persimmon diet showed no effect $(p>0.05)$ on moisture, crude protein and ash concentration, it significantly $(p<0.05)$ decreased crude fat concentration of LD.

Song et al. (2011) reported that dietary of 3, 5 and $10 \%$ fermented diet using the $76.0 \%$ rice bran, $20 \%$ dropped persimmon and $4.0 \%$ of other additives did not affected growth performance and feed efficiency in fattening pigs, because the energy value of fermented persimmon diet were formulated to meet or exceed the nutrient requirements recommended by NRC (1998). The results suggested that the low concentration of crude fat and low total calorie in diet may have decreased crude fat concentration of LD in fattening pigs.

\section{Physico-chemical characteristics}

The effects of dietary fermented persimmon diet on the physico-chemical characteristics, such as $\mathrm{pH}$, WHC, cooking loss and shear force of LD from fattening pigs is shown in Table 3 . The $\mathrm{pH}$ was significantly $(p<0.05)$ higher in $\mathrm{C}$ and $\mathrm{T} 3$ than in $\mathrm{T} 1$. The $\mathrm{pH}$ of meat is changed by nutrient values of diet (Rosenvold et al., 2003), and energy values of diet affect the concentration of macroglycogen in muscles and change the glycolysis and cooling rate of meat (McDonagh et al., 1999; Rosenvold et al., 2001). Current study measured concentration of glycogen, but it is well know that increased $\mathrm{pH}$ was a result of decreased glycogen concentration in meat (Rosenvold et al., 2001). Based on the results of this study, although the energy values of experimental diet did not differ between treatments and $\mathrm{C}$, the diet of T2 has $0.03 \mathrm{Mcal} /$ $\mathrm{kg}$ of low energy value compared with $\mathrm{C}$ diet. Hence, low energy values may have increased the $\mathrm{pH}$ of meat compared with others due to decrease glycogen concentration of pork.

Dietary of over than $5 \%$ fermented persimmon diet increased shear force, but imposed no effect on WHC and cooking loss. The WHC is an important factor for quality of fresh pork meat and affected by many factors after slaughter (Kwon et al., 1995). Cooking loss of meat is affected by soluble creatine and soluble fat (Carlin et al., 1965). Up to now, effects of fermented diets or probiotics on the WHC and texture analysis are not well understood (Jin et al., 2006; Kang et al., 2010). Further studies are

Table 3. Effects of supplemental fermented persimmon diet on the physico-chemical characteristics and meat color in longissimus dorsi of fattening pigs

\begin{tabular}{lccccc}
\hline \hline \multirow{2}{*}{ Items } & \multicolumn{5}{c}{ Treatments $^{1)}$} \\
\cline { 2 - 5 } & $\mathrm{C}$ & $\mathrm{T} 1$ & $\mathrm{~T} 2$ & $\mathrm{~T} 3$ & \\
\hline $\mathrm{pH}$ & $6.05^{\mathrm{b}}$ & $6.01^{\mathrm{b}}$ & $6.29^{\mathrm{ab}}$ & $6.62^{\mathrm{a}}$ & 0.15 \\
Water holding capacity, \% & 80.27 & 81.02 & 80.86 & 81.55 & 1.04 \\
Cooking loss, \% & 32.41 & 32.15 & 31.59 & 31.23 & 1.58 \\
Shear force, $\mathrm{kg} / \mathrm{cm}^{2}$ & $4.94^{\mathrm{b}}$ & $4.88^{\mathrm{b}}$ & $5.63^{\mathrm{a}}$ & $5.65^{\mathrm{a}}$ & 0.24 \\
\hline Meat color & & & & & \\
$\mathrm{CIE} \mathrm{L}^{*}$ & $47.94^{\mathrm{b}}$ & $49.04^{\mathrm{ab}}$ & $51.15^{\mathrm{a}}$ & $51.42^{\mathrm{a}}$ & 1.41 \\
$\mathrm{CIE} \mathrm{a}^{*}$ & 9.51 & 8.96 & 9.32 & 9.41 & 0.86 \\
$\mathrm{CIE} \mathrm{b}^{*}$ & $1.19^{\mathrm{a}}$ & $1.44^{\mathrm{a}}$ & $0.46^{\mathrm{b}}$ & $0.21^{\mathrm{b}}$ & 0.51 \\
\hline
\end{tabular}

${ }^{1)}$ The basal diet (C) was supplied 3\% (T1), 5\% (T2) and 10\% (T3) fermented persimmon diet.

${ }^{2)}$ Standard error of the means

${ }^{\mathrm{a}, \mathrm{b}}$ Values in the same row with different superscripts differ at $p<$ 0.05 . 
required to clarify the relationship between fermented diet and physico-chemical characteristics of meat, because of contradicted results of these parameters.

\section{Meat color}

Dietary of fermented persimmon diet had no effect on $\mathrm{a}^{*}$ (redness), but affected L* (lightness) and $\mathrm{b}^{*}$ (yellowness) of LD from fattening pigs. The lightness was significantly $(p<0.05)$ higher in T2 and T3 than in C, and the yellowness was significantly $(p<0.05)$ lower in $\mathrm{T} 2$ and $\mathrm{T} 3$ than in C and T1 (Table 3). Moreover, the fermented persimmon diet did not significantly $(p>0.05)$ affect the surface color (lightness, redness and yellowness) of backfat (not shown data).

Meat color is an important factor of pork quality and the most important factor that appeals to consumers who prefer high redness of pork meat. Meat color mainly affects by $\mathrm{pH}$ and temperature of meat during slaughter process (Lindahl et al., 2006). In this study, dietary of 5\% and $10 \%$ fermented persimmon diet increases lightness and decreased yellowness of pork, which suggested with Kang et al. (2010) who reported that dietary of fermented high energy diet using the agro by-products increased lightness of pork.

\section{Fatty acid composition}

The composition of palmitoleic acid, linoleic acid and arachidonic acid of LD from fattening pigs was not affected by dietary of fermented persimmon diet, but significantly $(p<0.05)$ increased the myristic acid and oleic acid composition and decreased $(p<0.05)$ the palmitic acid and stearic acid composition of LD. Moreover, the composition of unsaturated fatty acids (USFA) and ratio of USFA to saturated fatty acids (USFA/SFA) was significantly $(p<0.05)$ higher in treatments than in $\mathrm{C}$, while saturated fatty acids (SFA) composition was significantly $(p<0.05)$ lower, though dietary of fermented persimmon diet had no effect on the essential fatty acids (EFA) composition and ratio of EFA to USFA (EFA/USFA) of LD (Table 4).

The fatty acids composition of LD is changed by diet in monogastric animals (Pascual et al., 2007). In this study, the nutrient values of fermented persimmon diet might have increased USFA and decreased SFA composition. The concentration of total cholesterol and low density lipoprotein (LDL)-cholesterol in plasma were increased by SFA (Grundy et al., 1982) and decreased by USFA (Becker et al., 1983) in diet. A high level of USFA and low level of SFA in LD is more beneficial to human
Table 4. Effects of supplemental fermented persimmon diet on the fatty acid composition in longissimus dorsi of fattening pigs

\begin{tabular}{lrrrrr}
\hline \hline & \multicolumn{5}{c}{ Treatments $^{1)}$} \\
\cline { 2 - 5 } Items & $\mathrm{C}$ & $\mathrm{T} 1$ & $\mathrm{~T} 2$ & $\mathrm{~T} 3$ & \\
\hline Fatty acid composition, \% & & & & & \\
Palmitic acid & $20.71^{\mathrm{a}}$ & $18.00^{\mathrm{b}}$ & $18.20^{\mathrm{b}}$ & $17.92^{\mathrm{b}}$ & 0.71 \\
Palmitoleic acid & 2.36 & 2.70 & 2.63 & 2.63 & 0.61 \\
Stearic acid & $10.14^{\mathrm{a}}$ & $8.64^{\mathrm{b}}$ & $8.49^{\mathrm{b}}$ & $8.57^{\mathrm{b}}$ & 0.53 \\
Oleic acid & $36.48^{\mathrm{b}}$ & $39.11^{\mathrm{a}}$ & $38.76^{\mathrm{a}}$ & $38.86^{\mathrm{a}}$ & 1.07 \\
Linoleic acid & 21.24 & 23.09 & 23.01 & 22.97 & 0.88 \\
Arachidonic acid & 8.45 & 7.66 & 8.13 & 8.24 & 0.80 \\
\hline Saturated fatty acid (SFA) & $31.47^{\mathrm{a}}$ & $27.44^{\mathrm{b}}$ & $27.47^{\mathrm{b}}$ & $27.30^{\mathrm{b}}$ & 0.49 \\
Unsaturated fatty acid (USFA) & $68.53^{\mathrm{b}}$ & $72.56^{\mathrm{a}}$ & $72.53^{\mathrm{a}}$ & $72.70^{\mathrm{a}}$ & 0.90 \\
Essential fatty acid (EFA) & 29.69 & 30.75 & 31.14 & 31.21 & 0.97 \\
USFA/SFA & $2.178^{\mathrm{b}}$ & $2.644^{\mathrm{a}}$ & $2.640^{\mathrm{a}}$ & $2.663^{\mathrm{a}}$ & 0.083 \\
EFA/USFA & 0.433 & 0.424 & 0.429 & 0.429 & 0.078 \\
\hline${ }^{1)}$ The basal diet (C) was supplied 3\% & (T1), 5\% (T2) and $10 \%$ (T3) \\
fermented persimmon diet. & & & & \\
${ }^{2)}$ Standard error of the means \\
a,b Values in the same row with different superscripts differ at $p<$ \\
0.05.
\end{tabular}

health, such as prevention of arteriosclerosis and hypertension (Decker and Shantha, 1994; Engler et al., 1991). Hence, from results of this study, dietary of fermented persimmon diet may have improved fatty acid compositions of LD that maybe beneficial to human health. The meat flavor showed positive correlation with the concentration of SFA and mono-UFA (MUFA), but has negatively correlated with the concentration of poly-UFA (PUFA) in meat (Cameron and Enser, 1991). The ratio of MUFA to SFA (MUFA/SFA) of meat was used as an indirect index for meat taste (Anderson et al., 1975; Janicki and Appledorf, 1974). In this study, dietary of fermented persimmon diet affected sensory characteristics due to increased composition of MUFA/SFA of LD from fattening pigs. Hence, dietary of fermented persimmon diet affected fatty acid composition of LD towards the benefit of human health by increasing USFA and decreasing SFA composition of LD.

\section{Texture profile analysis}

Dietary of fermented persimmon diet showed no effect $(p>0.05)$ on hardness, cohesiveness, gumminess and chewiness, but significantly $(p<0.05)$ decreased adhesiveness of $\mathrm{LD}$ in treatments compared with $\mathrm{C}$ and the springiness was significantly lower $(p<0.05)$ in $\mathrm{T} 2$ and $\mathrm{T} 3$ than in $\mathrm{C}$ (Table 5).

Tenderness of meat is the most important factor for evaluation of pork meat and animal products, though 
Table 5. Effects of supplemental fermented persimmon diet on the texture profile analysis in longissimus dorsi of fattening pigs

\begin{tabular}{llllll}
\hline \multirow{2}{*}{\multicolumn{1}{c}{ Items }} & \multicolumn{5}{c}{ Treatments $^{\mathrm{l})}$} \\
\cline { 2 - 5 } & \multicolumn{1}{c}{$\mathrm{C}$} & \multicolumn{1}{c}{$\mathrm{T} 1$} & $\mathrm{~T} 2$ & $\mathrm{~T} 3$ & \\
\hline Hardness & 1.43 & 1.41 & 1.44 & 1.47 & 0.26 \\
Cohesiveness & 0.41 & 0.42 & 0.42 & 0.42 & 0.15 \\
Springiness & $1.20^{\mathrm{a}}$ & $1.09^{\mathrm{ab}}$ & $1.02^{\mathrm{b}}$ & $1.03^{\mathrm{b}}$ & 0.09 \\
Gumminess & 0.68 & 0.67 & 0.67 & 0.67 & 0.01 \\
Chewiness & 0.81 & 0.81 & 0.82 & 0.81 & 0.04 \\
Adhesiveness & $1.69^{\mathrm{a}}$ & $1.41^{\mathrm{b}}$ & $1.43^{\mathrm{b}}$ & $1.48^{\mathrm{b}}$ & 0.13 \\
\hline
\end{tabular}

${ }^{1)}$ The basal diet (C) was supplied 3\% (T1), 5\% (T2) and 10\% (T3) fermented persimmon diet.

2) Standard error of the means

${ }^{\mathrm{a}, \mathrm{b}}$ Values in the same row with different superscripts differ at $p<$ 0.05 .

appearance, meat color, flavor, taste and juiciness are also important factors to consumers (Bailey, 1972). It was reported that dietary of probiotics had no effect on TPA of LD from fattening pigs (Jin et al., 2006) but it was greatly affected by fatty acids composition in LD (Wood et al., 2008). In this study, dietary of fermented persimmon diet may have changed TPA of LD due to the change of crude fat concentration and fatty acids composition of LD.

\section{Sensory evaluation}

The results of fresh meat were not affected by the dietary of fermented persimmon diet as well its marbling and overall acceptability, but significantly $(p<0.05)$ increased drip loss of LD from fattening pigs. The drip loss was significantly $(p<0.05)$ higher in T2 and T3 than in C. In the case of cooked meat, dietary of fermented persimmon diet significantly $(p<0.05)$ increased the aroma, taste, juiciness and overall acceptability of LD. The color and hardness were significantly $(p<0.05)$ higher in T3 than in C (Table 6).

Evaluation of meat quality is depends on physicochemical analysis and sensory evaluation and these methods are affected by the animal breed, heritability, sex, feeding conditions, fatting rate, slaughter process, treatment conditions of carcass, storage days, muscle part and so on (Joo et al., 2002). Tenderness and juiciness of meat were correlated with the concentration of crude fat, WHC and cooking loss (Wood et al., 2008). In this study, dietary of fermented persimmon diet increased sensory evaluation of cooked meat from fattening pigs. The abundant concentration of trace factors and fiber in fermented diet decreased off-flavor of pork, suppressed production of soft yellowness fat and improved carcass grades (Lee et
Table 6. Effects of supplemental fermented persimmon diet on the sensory evaluation ${ }^{1)}$ in fresh and cooked longissimus dorsi of fattening pigs

\begin{tabular}{llllll}
\hline \multirow{2}{*}{ Items } & \multicolumn{5}{c}{ Treatments $^{2)}$} \\
\cline { 2 - 5 } SEM $^{3)}$ & $\mathrm{C}$ & $\mathrm{T} 1$ & $\mathrm{~T} 2$ & $\mathrm{~T} 3$ & \\
\hline Mesh meat & & & & & \\
Drip loss & 6.50 & 6.61 & 6.80 & 6.77 & 0.77 \\
Marbling & $7.97^{\mathrm{b}}$ & $7.37^{\mathrm{b}}$ & $6.67^{\mathrm{a}}$ & $6.61^{\mathrm{a}}$ & 0.41 \\
Overall acceptability & 5.73 & 5.79 & 6.20 & 6.30 & 0.83 \\
Cooked meat & 6.40 & 6.21 & 6.80 & 6.93 & 0.81 \\
Color & & & & & \\
Aroma & $6.93^{\mathrm{b}}$ & $7.10^{\mathrm{ab}}$ & $7.10^{\mathrm{ab}}$ & $7.30^{\mathrm{a}}$ & 0.21 \\
Taste & $6.63^{\mathrm{b}}$ & $7.10^{\mathrm{a}}$ & $7.11^{\mathrm{a}}$ & $7.20^{\mathrm{a}}$ & 0.24 \\
Juiciness & $6.73^{\mathrm{b}}$ & $7.37^{\mathrm{a}}$ & $7.37^{\mathrm{a}}$ & $7.47^{\mathrm{a}}$ & 0.27 \\
Hardness & $6.90^{\mathrm{b}}$ & $7.30^{\mathrm{a}}$ & $7.30^{\mathrm{a}}$ & $7.33^{\mathrm{a}}$ & 0.16 \\
Overall acceptability & $6.87^{\mathrm{b}}$ & $7.03^{\mathrm{ab}}$ & $7.03^{\mathrm{ab}}$ & $7.37^{\mathrm{a}}$ & 0.17 \\
\hline Values were scored & $7.18^{\mathrm{a}}$ & $7.18^{\mathrm{a}}$ & $7.39^{\mathrm{a}}$ & 0.16 \\
\hline
\end{tabular}

${ }^{1)}$ Values were scored 9 point scale based on 1 (extremely bad or slight) to 9 (extremely good or much).

${ }^{2)}$ The basal diet (C) was supplied 3\% (T1), 5\% (T2) and 10\% (T3) fermented persimmon diet.

${ }^{3)}$ Standard error of the means

${ }^{\mathrm{a}, \mathrm{b}}$ Values in the same row with different superscripts differ at $p<$ 0.05 .

al., 1998; Song et al., 2001). Therefore, dietary of fermented persimmon diet might be used to produce pork from fattening pigs with appealing features to such as color to consumers.

\section{Conclusion}

The results of this study indicated that the fermented persimmon diet decreased the concentration of crude fat, yellowness of meat and SFA composition, while increased lightness of meat, USFA composition and sensory evaluation of LD muscles from fattening pigs. This improved sensory evaluation could be due to decreased crude fat concentration and improved fatty acids composition that was noticed as increased USFA composition and decreased SFA composition of LD from fattening pigs. Further, investigations are required to clarify the effects of fermented persimmon diet on the mechanisms that affect meat quality and its sensory evaluation parameters, which in turn affect consumer's decision to buy pork.

\section{Acknowledgements}

This work was supported by the Priority Research Centers Program through the National Research Foundation of Korea (NRF) funded by the Ministry of Education, 
Science and Technology (2009-0093813) and the Cooperative Research Program for Agriculture Science \& Technology Development (Project No.PJ0077672011) funded by Rural Development Administration, Republic of Korea.

\section{References}

1. Anderson, D. A., Kisellan, J. A., and Watt, B. K. (1975) Comprehensive evaluation of fatty acid in beefs. J. Anim. Diet Assoc. 67, 35-43.

2. Association of Official Analytical Chemists (AOAC). (2000) Official method of analysis. 16th ed., AOAC, Washington, DC.

3. Bailey, A. J. (1972) The basis of meat texture. J. Sci. Food Agri. 23, 995-1007.

4. Becker, N., Illingworth, D. R., Alaupovic, P., Connor W. E., and Sundberg E. E, (1983) Effect of saturated monounsaturated and $\omega-6$ polyunsaturated fatty acids on plasma lipids, lipoproteins and apoproteins in humans. Am. J. Clin. Nutr. 37, 355-360.

5. Bourne, M. C. (1978) Texture profile analysis. Food Tech. 32, 62-66.

6. Cameron, N. D. and Enser, M. (1991) Fatty acid composition of lipid in longissimus dorsi muscle of Duroc and British Landrace pigs and its relationship with eating quality. Meat Sci. 29, 295-307.

7. Canibe, N. and Jensen, B. B. (2007) Fermented liquid feed and fermented grain to piglets-effect on gastrointestinal ecology and growth performance. Livestock Sci. 108, 198-201.

8. Carlin, F. C., Bloemer, D. M., and Hotchkiss, D. K. (1965) Relation of oven temperature to quality of pork loin roasts. $J$. Home Econ. 57, 442-446.

9. Chae, B. J., Choi, S. C., Kim, Y. G., Kim, C. H., and Sohn, K. S. (2000) Effects of feeding dried food waste on growth and nutrient digestibility in growing-finishing pigs. Asian-Aust. J. Anim. Sci. 13, 1304-1308.

10. Decker, E, A. and Shantha, N. C. (1994) Concentrations of the anticarcinogen, conjugated linoleic acid in beef. Meat Focus Int. 3, 61-69.

11. Duncan, D. B. (1955) Multiple range and multiple F tests. Biometrics. 11, 1-42.

12. Engler, N. M., Karanian, J. W., and Salem, J. M. (1991) Influence of dietary polyunsaturated fatty acids on aortic and plate fatty acid composition in the rat. Nutr. Res. 11, 753-762.

13. Gorinstein, L., Gustaw, W. K., Elzbieta, B., Marial, L., and Silmon, T. (1998) The influence of persimmon peel and persimmon pulp on the lipid metabolism and antioxidant activity of rats fed cholesterol. J. Nutr. Biochem. 9, 223-227.

14. Grundy, S. M., Bilheimer, D., Blackburn, H., Brown, W. V., Kwiterovich, P. O., Mattson, F., and Wiedman, W. H. (1982) Rationale of the diet-heat statement of the American Heart Association Report of Nutrition Committee, Circulation, 65, 839.

15. Honikel, K. O. (1998) Reference methods for the assessment of physical characteristics of meat. Meat Sci. 49, 447-457.
16. Janicki, L. J. and Appledorf, H. (1974) Effect of boiling, grilling, frying and microwave cooking on moisture, some lipid components and total fatty acids of ground beef. $J$. Food Sci. 39, 715-723.

17. Jin, S. K., Kim, I. S., Song, Y. M., Ha, J. H., Park, K. H., Lee, J. I., Lee, J. R., and Lee, C. W. (2006) Effects of feeding probiotics on quality properties of pork. Kor. J. Food Sci. An. 26, 49-57.

18. Joo, S. T., Lee, J. I., Ha, Y. L., and Park, G. B. (2002) Effects of dietary conjugated linoleic acid on fatty acid composition, lipid oxidation, color and water-holding capacity of pork loin. J. Anim. Sci. 80, 108-112.

19. Kang, S. N., Song, Y. M., Kim, C.W., Kim, T. W., Chu, G. M., Yang, B. S., Jin, S. K., and Kim, I. S. (2010) Effect of feeding high carbohydrate-low fat fermented feed on the meat quality characteristics in finishing pig. Kor. J. Food Sci. An. 30, 826-832.

20. Kim, H. Y., Song, Y. M., Kang, Y. S., Kim, C. H., Lee, S. D., Chowdappa, R, . Ha, J. H., and Kang, S. M. (2006) The effect of fermented persimmon shell diet supplementation on the growth performance and blood parameters in fishing pigs. Anim. Sci. J. 77, 314-319.

21. Kwon, Y. J., Yeo, J. S., and Sung, S. K. (1995) Quality characteristics of Korean native chicken meat. Kor. J. Poult. Sci. 22, 223-231.

22. Lindahl, G., Enfalt, A. C., Andersen, H. J., and Lundstrom, K. (2006) Impact of RN genotype and storage time on colour characteristics of the pork muscles longissimus dorsi and semimembranosus. Meat Sci. 74, 746-755.

23. Lee, J. I., Chung, M. S., Hwangbo, J., Park, B. Y., Park, T. S., Kim, J. H., Sung, P. N., and Park, G. B. (1998). Effects of fermented sawdust feeds and powdered fish oil in diet on the shelf-life of pork. Kor. J. Anim. Sci. Tech. 40: 69-78.

24. Lee, S. W., Ham, S. N., Shin, T. S., Kim, H. K., Yeon, I. J., and Kim K. Y. (2009) Resource of food waste using indigenous bacteria isolated from soils. Kor. J. Environ. Eng. 31, 35-41

25. McDonagh, M. B., Fernandez, C., and Oddy, V. H. (1999) Hind-limb protein metabolism and calpain system activity influence post-mortem change in meat quality in lamb. Meat Sci. 52, 9-18.

26. Meilgaard, M., Civille, G. V., and Carr, B. T. (1991) Affective tests: Consumer tests and in-house panel acceptance tests. In: Sensory evaluation techniques. 3rd edn, CRC Press Inc, Boca Ranton, FL, pp 211-222.

27. National Research Council (NRC) (1998). Nutrient Requirements of Swine. 9th ed. National Academic Press, Washington, DC.

28. Pascual, J. V., Rafecas, M., Canela, M. A., Boatella, J., Bou, R., and Barroeta, A. C. (2007) Effect of increasing amounts of a linoleic-rich dietary fat on the fat composition of four pig breeds. Part: Fatty acid composition in muscle and fat tissue. Food Chem. 100, 1639-1648.

29. Rosenvold, K., Essen-Gustavsson, B., and Andersen, H. J. (2003) Dietary manipulation of pro- and macro-glycogen in porcine skeletal muscle. J. Anim. Sci. 81, 130-134. 
30. Rosenvold, K., Laerke, H. N., Jensen, S. K., Karlsson, A. H., Lundström, K., and Andersen, H. J. (2001) Strategic finishing feeding as a tool in the control of pork quality. Meat Sci. 59, 397-406.

31. SAS (2008) SAS/STAT Software for PC. Release 9.2, SAS Institute, Cary, NC, USA.

32. Seo, J. H., Jeong Y. J., and Kim, K. S. (2000) Physiological characteristics of tannins isolated from astringent persimmon fruits. Kor. J. Food Sci. Technol. 32, 212-217.

33. So, M. H. (1999) Current drive and counter plan for recycling of food waste as animal feed. Symposium on Recycling of Food Waste as Feed, 1999. National Livestock Research Institute, Suwon, Korea.

34. Song, Y. M., Jin, S. K., Lee, S. D., Ha, K. H., and Chung, M. H. (2001) Effects of piggery type (or structure) and the dietary fermentation feedstuffs on meat quality in finishing pigs. Kor. K. Intl. Agri. 14, 169-175.

35. Song, Y. M., Chu, G. M., Ha, J. H., Lee, H. J., Kim, S. C., and Kim, H. Y. (2011) Effects of fermented diet using probiotics from pine needle microbes on growth performance, blood characteristics, carcass traits and economy of pig. J. Agri. Life Sci. 45, 93-101.

36. Szczceniak, A. S. (1963) Classification of textural characteristics. J. Food Sci. 28, 385-389.

37. Taira, S., Itamura, H., and Abe K. (1990) Effects of harvest maturity on removal of astringency in Japanese persimmon (Diospyros kaki Thumb), Hiratanenashi fruit. J. Jpn. Soc. Hort. Sci. 58, 813-818.

38. Way, P. and Hanahan, D. J. (1964) Characterization and quantification of red cell lipids. J. Lipid Res. 5, 318-328.

39. Westendorf, M. L. (2000) Food waste as animal feed: An introduction, Food Waste to Animal Feed, Iowa State University Press, Ames, Iowa, USA.

40. Wood, J. D., Enser, M., Fisher, A. V., Nute, G. R., Sheard, P. R., Richardson, R. I., Hughes, S. I., and Whittington F. M. (2008) Fat deposition, fatty acid composition and meat quality: A review. Meat Sci. 78, 343-358.

(Received 2012.4.30/Revised 2012.7.12/Accepted 2012.9.27) 